\title{
Pornography, Its Harms, and a New Legal Strategy: Research and Experience in Japan
}

\author{
Seiya Morita \\ Kokugakuin University,fs_tr_mrt@yahoo.co.jp \\ Caroline Norma \\ RMIT University, caroline.norma@rmit.edu.au
}

Follow this and additional works at: https://digitalcommons.uri.edu/dignity

Part of the Civil Law Commons, Civil Rights and Discrimination Commons, Community-Based Research Commons, Criminal Law Commons, Domestic and Intimate Partner Violence Commons, Human Rights Law Commons, Inequality and Stratification Commons, Japanese Studies Commons, Law and Gender Commons, Law and Politics Commons, Public Policy Commons, Sexuality and the Law Commons, Social Justice Commons, Social Policy Commons, and the Women's Studies Commons

\section{Recommended Citation}

Morita, Seiya and Norma, Caroline (2021) "Pornography, Its Harms, and a New Legal Strategy: Research and Experience in Japan," Dignity: A Journal of Analysis of Exploitation and Violence: Vol. 6: Iss. 2, Article 3. https://doi.org/10.23860/dignity.2021.06.02.03

This Research and Scholarly Article is brought to you for free and open access by DigitalCommons@URI. It has been accepted for inclusion in Dignity: A Journal of Analysis of Exploitation and Violence by an authorized editor of DigitalCommons@URI. For more information, please contact digitalcommons-group@uri.edu. 


\title{
Pornography, Its Harms, and a New Legal Strategy: Research and Experience in Japan
}

\begin{abstract}
In this article we describe pornography's harms in Japan, which are known about from surveys and research, and from the outreach and consulting activities of Japanese feminist-abolitionist groups. Among these are the Anti-Pornography and Prostitution Research Group (APP) and People Against Pornography and Sexual Violence (PAPS). We then propose a renewed classification scheme for pornography's harms that centrally considers the experiences of victims in Japan. Lastly, we consider various legal approaches to addressing the myriad harms we describe and suggest possibilities for a new legal strategy. The article's research comes from Japanese-language materials produced by the abovementioned activist groups, as well as media reports of pornography-related crimes and court cases. Our aim in this article is to isolate each category of pornography's harms so that individually tailored legal and public policy solutions might be tactically proposed and campaigned for, so that gains against the pornography industry can be made to the point where its operating environment as a whole becomes threatened.
\end{abstract}

\section{Keywords}

Japan, pornography, harm, legal approach, strategy, research, MacKinnon-Dworkin Ordinance

\section{Creative Commons License}

(c) (i) $\ominus$

This work is licensed under a Creative Commons Attribution-Noncommercial-No Derivative Works 4.0 License.

\section{Acknowledgements}

The authors thank members of the Anti-Pornography and Prostitution Research Group (APP) and People Against Pornography and Sexual Violence (PAPS). Dignity thanks the following people for the time and expertise to review this article: Catharine A. MacKinnon, Elizabeth A. Long Professor of Law at University of Michigan Law School; and Hiroshi Nakasatomi, Osaka Electro-Communications University. 


\title{
DIGNITY A JOURAL OF ANALYISIS
}

Volume 6, Issue 2, Article 3, 2021

https://doi.org/10.23860/dignity.2021.06.02.03

\section{PORNOGRAPHY, ITS HARMS, AND A NEW LEGAL STRATEGY: RESEARCH AND EXPERIENCE IN JAPAN}

\author{
Seiya Morita \\ Kokugakuin University, Japan \\ https://orcid.org/0000-0002-8343-1265
}

\author{
Caroline Norma \\ RMIT University, Australia \\ https://orcid.org/0000-0002-6836-2054
}

\begin{abstract}
In this article we describe pornography's harms in Japan, which are known about from surveys and research, and from the outreach and consulting activities of Japanese feminist-abolitionist groups. Among these are the Anti-Pornography and Prostitution Research Group (APP) and People Against Pornography and Sexual Violence (PAPS). We then propose a renewed classification scheme for pornography's harms that centrally considers the experiences of victims in Japan. Lastly, we consider various legal approaches to addressing the myriad harms we describe and suggest possibilities for a new legal strategy. The article's research comes from Japanese-language materials produced by the above-mentioned activist groups, as well as media reports of pornography-related crimes and court cases. Our aim in this article is to isolate each category of pornography's harms so that individually tailored legal and public policy solutions might be tactically proposed and campaigned for, so that gains against the pornography industry can be made to the point where its operating environment as a whole becomes threatened.
\end{abstract}

\section{KEYWORDS}

Japan, pornography, harm, legal approach, strategy, research, MacKinnon-Dworkin Ordinance

$A^{\prime}$ FTER THE UNITED STATES, JAPAN IS ONE OF THE WORLD'S largest producers of pornography. Pornography produced in Japan is consumed in large volume on the Internet by men in Japan and men in China, South Korea, and Taiwan. According to the 2019 Year in Review statistical analysis of the world's largest online pornography site Pornhub, the site's most view pornographic category "Japanese" is popularly accessed not just from within Japan, but also South Korea, China, Taiwan and Southeast Asia. (Pornhub, 2019). In addition, Japanese pornographic manga and animation, called hentai, is consumed worldwide. While such a large pornography-producing country like Japan necessarily brings about vast harms, it is also a country with a long history of grassroots community action to address these harms, as well as research and empirical data collection of its profound effects.

Accordingly, in this article, we describe pornography's harms in Japan, which are known about from surveys and research, and from the supporting and consulting activities of Japanese feminist-abolitionist groups. Among these are the Anti-Pornography-and-Prostitution Research Group (APP), founded in 1999, and People Against Pornography and Sexual Violence (PAPS), founded in 2009. We then propose a re- 
newed classification scheme for pornography's harms that centrally considers the experiences of victims in Japan. Lastly, we consider various legal approaches to addressing the myriad harms we describe and suggest possibilities for a new legal strategy.

This article's research and perspective contribute to an academic field that assesses legal and legislative approaches to suppression of the commercial pornography industry in different country jurisdictions. The field's pioneer is Max Waltman, who examines anti-pornography executive and judicial initiatives in Sweden, Canada, and the United States (2014). In this work, Waltman asks from a critical perspective, "What is in the way of successfully challenging pornography as such in democratic legal systems?" (p. 13), and comprehensibly identifies structural and social barriers to official action against the industry. In 2016, Elza Ibroscheva undertook a similar analysis of Bulgaria, even if more limitedly. Earlier, in 2012, Bin Liang and Hong Lu assessed measures in the People's Republic of China, but not from any perspective critical of the sex industry. This article contributes knowledge of Japan to this existing body of research. It follows Waltman in categorizing its assessment of Japanese judicial and legislative responses according to the specific harms of pornography they seek to address.

\section{From an Obscenity to a Discrimination Approach}

The notion that the problem of pornography is one of social order or unhealthy sexual morals or one of sexual shame or public indecency has prevailed everywhere in the world since the nineteenth century, including in Japan. The notion established a standard for anti-pornography laws almost everywhere, including in Japan. Obscenity law loosely restricts the public dissemination of so-called obscene materials from the viewpoint of maintaining a healthy social order (the obscenity approach). In Japan, as elsewhere, obscenity in criminal law has been treated as a typical example of a crime without a victim, and so it has been relentlessly criticized by people (liberals) who demand full freedom of speech, including that of pornography or rather freedom of access to pornography.

In the 1970s, the radical feminist movement in the US and other countries opposed this trend by arguing that pornography is political propaganda of sex discrimination and a misogynist ideology against women. They argued that pornography comprises not just sexually explicit materials but also material of a sexually dominating and subjugating nature that turns women into sex objects for sexual exploitation by men (the sexist propaganda approach). They also insisted that it causes many rapes. Robin Morgan's famous slogan, "Pornography is the theory; rape is the practice"” (1977), was a lucid formulation of this new approach.

But the new approach had two limitations. First, it highlighted only a few of pornography's harms, and its concern was restricted mainly to the sexist message of pornography and the harmful effects of this message on women and girls. Second, it took over a political tradition of liberalism in relation to the relationship between civil society and the state and law, so it did not believe in any legal restriction or governmental intervention against pornography, however sexist it was. Therefore, its proponents combatted pornography mainly through their own speech, and sometimes through guerrilla-like direct action, such as that of Nikki Craft (No Status Quo, n.d.). These were bold and brave struggles, but due to often accompanying illegal acts, the movement suffered damage, and not a few militants were arrested (Dworkin, 1993). Catharine MacKinnon, a feminist legal scholar, and Andrea Dworkin, a feminist writer, broke through these practical and theoretical barriers. 
While MacKinnon and Dworkin built upon the existing radical feminist sexist propaganda approach, they also renovated it on two points. Firstly, they maintained that pornography was sexist propaganda against women and girls and a practice in itself concretely and directly violating of civil rights. So, and as their second renovation, they advocated its legal restriction in terms of legislation that would provide pornography's victims avenues of civil redress. To be sure, the first change towards adopting a sexist propaganda approach instead of an obscenity approach was fundamental. However, it was still a shift contained within the bounds of the pornography as expression paradigm.

\section{MacKinnon and Dworkin's Paradigm Shift}

Of course, radical feminists already understood and condemned the fact that the dissemination and spread of pornography leads to declines in women's status and aggravates sexism among men, and that mass pornography consumption lowers psychological barriers to the rape of women and girls, and so promotes the crime. In other words, they did understand pornography's practical aspects as intertwined with many real-life practices and injuries. But, as Robin Morgan's slogan reflected, pornography remained theory, not practice. The implicit assumption was that it could give rise to practices of various kinds but was not a practice in itself. In opposition to this standpoint, MacKinnon said:

Robin Morgan once said, 'pornography is the theory, rape is the practice.' This is true, but Andrea Dworkin's revision is more true: 'Pornography is the theory, pornography is the practice' $(1991$, p. 21$){ }^{1}$

In other words, pornography is not just a theory of women's subordination, far from mere expression, even if a sexist manifestation of it, but also an ensemble of whole acts of discrimination and violence causing actual sexual harms and concrete human rights violations at every phase of its production, circulation, consumption, and even though its continuing existence.

To come to this new insight, it was crucially important to find victims of pornography's production. Women formerly in pornography abused in its production who stepped forward publicly became its starting point. They knew of MacKinnon, who had devised an inequality approach towards workplace sexual harassment and had achieved success in its legal restriction, so they came to her and asked her to formulate a new legal approach that could give legal relief for their harms sustained in pornography. Therefore, a new movement based on the new approach incorporated victims from the outset; it was not the result of academic concept-making, nor was it a paternalistic movement of uninvolved activists. At an abolitionist event held in Tokyo in January 2002, MacKinnon talked about her engagement with this movement.

\footnotetext{
${ }^{1}$ Morgan did, nonetheless, support MacKinnon and Dworkin's anti-pornography ordinance and wrote a letter of endorsement to Minneapolis City Council. See Letter of Robin Morgan, December 5, 1983, in Catharine A. MacKinnon \& Andrea Dworkin eds., In harm's way: the pornography civil rights hearings, Cambridge, MA: Harvard University Press, 1998, pp. 221-223. In it she said, "[t]his is written in support of the proposed legislation before the Council which would include pornography as a practice discriminatory against and degrading/endangering to the civil rights of female citizens of your city" (p. 221). Thus, she explicitly called pornography a practice against women.
} 
I know about prostitution and pornography because the survivors of both of them [pornography and prostitution] have told me about it, about their experience in it. They are the source of my knowledge of this problem. They came to me to tell me what did happen to them and asked me to do something about it. This work does not start with a theory. It does not start with something that is already in a book. For me, it started with real women's lives, and with our work together on this issue for over twenty years. So, to the question, "Why do I deal with this issue?" the first simple answer is that women asked me to deal with this issue. ${ }^{2}$

As MacKinnon says, "The harm of pornography begins with the women in it" (2005, p. 301). Finding out this fact was crucial in the historical transition from the expression or theory approach to the practice or harms approach. It is not just that some concrete harms in practice derive from what is a form of expression or a set of ideas, but, oppositely, what is fundamentally violation in practice necessarily causes other harms, including ones of expression.

So, pornography is no longer a mere theory, even if one for rape, and no longer mere expression, even if sexist. Making a law tackling harms produced by it and giving its victims judicial remedies, therefore, no longer presents a problem in tension with constitutional values of freedom of speech. It departs from a legal agenda in the field of expression and enters a legal one in the field of concrete action.

\section{From the MacKinnon-Dworkin Ordinance to "Anti-Pornography and Prostitution Research Group's" Classification}

MacKinnon and Dworkin jointly drafted an anti-pornography civil rights ordinance in 1983. Crucially, its drafting responded to the narratives and experiences of victims of pornography. The ordinance, in turn, classified these narratives and experiences into five categories of pornography's harms, which were proposed as causes of action under the law. The first category was coercion into pornography. This is a harm in which a person is forced to perform or become an object of pornography against her will by means of force or assault, threat or intimidation, fraud or deception, or even psychological pressure. The MacKinnon-Dworkin Ordinance incorporates the explicit provision that even when "the person signed a contract," this fact doesn't "negate a finding of coercion" (MacKinnon \& Dworkin, 1988, p. 42). As we will see below, this first type of harm, in the twenty-first century, became the main focus of the problem in Japan and eventually prompted policymaking action.

The second category was forcing pornography on a person, which is harm involving a person being forcibly exposed to pornography at home or work. Today, when such a harm occurs within a household, it is also seen as a form of domestic violence, and when it occurs within a workplace, it is recognized as a form of sexual harassment. So, this type of harm is indivisibly intertwined with other forms of violence against women.

The third category of pornography's harms is sexual assault due to pornography. This category assumes that a man (usually) who repeatedly and continually watches certain forms of pornography (especially of a violent kind) and whose psychological inhibition to sexual assault is lowered enacts sexual assault (including rape, but not exclusively) against other persons (mostly women or children). In fact, by repeated

${ }^{2}$ Her quoted words here are taken from an English-language recording of the event on file with the first author. 
and continual watching of violent pornography, many perpetrators of serial-rape or sexual murders learn to make dominance and violence against women a behavior of sexual pleasure, pick out specific targets or prey, and pick up methods of assault and abuse.

The fourth category is the trafficking of pornography, which is a harm that arises through pornography's dissemination and distribution. It is a category of harm that, in addition to the other four categories identifies compounding harms of pornography in terms of its impact upon women's population-level status, in addition to the harms suffered by individuals victimized by it. The trafficking of pornography inflicts harm upon the female population by lowering their position relative to men and exacerbating the despised status of its individual members.

The fifth category of pornography's harms is what MacKinnon and Dworkin call defamation through pornography. Pornography's technological level is sometimes low and elementary, but sometimes remarkably high: from sticking a photograph of a targeted woman's face and a photograph of a pornography actress's naked body together with glue to using image processing software to make a fake image or motion picture appear authentic. This kind of harm includes using someone's real name in a pornographic context or a sexual and defamatory magazine article. Celebrities and anti-pornography feminists are most often targeted for this kind of attack.

MacKinnon and Dworkin thus clarified different kinds of pornography's harms and collaborated with victims to establish a comprehensive civil remedy for them. This remedy was realized as ordinances in some cities in the US, but these were all eventually struck down in the courts as unconstitutional. However, these efforts to advance new conceptualizations of the harms of pornography and elucidate them were eternally significant.

Japan's feminist anti-pornography groups, the Anti-Pornography and Prostitution Research Group (APP) and People Against Pornography and Sexual Violence (PAPS), actively learned from their achievements, and researched various harms of pornography to establish a classification system for harms in Japan. APP expanded upon the Ordinance's five categories of harm to nominate additional forms of harm for the purpose of considering tailored, specific laws and policies to address each category. The expanded APP categories are: harms in production; harms in circulation; harms in consumption; social harms; and harms in existence, as summarized in Table 1.

\section{Harms in Production}

The harm of pornography starts with the women used in it. Although these harms are the starting place for all other harms, they tend to be ignored or forgotten. Curiously, when people talk about child pornography, they focus exclusively on the human rights of children used in it; but, when people talk about adult pornography, the human rights of women used in it are thoroughly forgotten, and even people who question pornography make an issue only of its sexist influence. As opposed to this, in the case of child pornography, because its socially harmful consequences tend to be ignored, many men in Japan assume that child-pornographic manga and animation are victimless. But in both child pornography and its adult equivalent, the first victims are 
Table 1: Anti-Pornography and Prostitution Research Group's Classification of Pornography's Harms

\section{Production Harms}

1. Harms arising in the production process of commercial pornography

2. Harms arising in the production of non-commercial pornography a. Footage taken of a naked victim or sexual acts coerced through assault, threats, or fraud, or under the circumstances making refusal difficult, e.g., contract fees, psychological pressure, inducement by family or intimate partners, or the abuse of power by people in positions of authority

b. Footage taken of a naked victim or sexual acts not agreed to, or different from those agreed to

c. Footage taken of a naked victim or sexual acts agreed to but severely violating of a person's human dignity, safety, or health

a. Footage or photographs taken of a victim in the course of sexual assault perpetration

b. Footage of a naked victim or sexual acts by family members or partners without consent

c. Coerced sexual selfies

3. Harms of being a victim of spycam filming

\section{Circulation Harms}

1.Harms arising through the circulation of materials produced in the above-mentioned ways

2. Non-consensual circulation a. The non-consensual circulation of sexual pictures taken consensually

b. The non-consensual continued circulation of films

3. The circulation and dissemination of pornographic collage pictures

\section{Consumption Harms}

1. Forced pornographic acts or pictures in the home or workplace

2. Sexual assault induced by pornography consumption a. Forced exposure to pornography in the home or workplace (e.g., as part of domestic violence, child sexual abuse, or environmental sexual harassment)

b. Forced enactment of pornography in domestic relationships 
Table 1: Anti-Pornography and Prostitution Research Group's Classification of Pornography's Harms (continued)

\section{Social Harms}

1. Psychological harm experienced as a result of exposure to widely circulating violent pornography (i.e., environmental pornographic harm)

2. The exacerbation of sex discrimination and misogyny as a result of the widespread dissemination of pornography

\section{Harms of Existence}

1. The shame and fear of victims who have been harmed in pornography is prolonged while the materials are still accessible

2. Consensual pornography later used to intimidate or harass victims

the persons themselves used in producing it. The harms of production category encompasses three items: (1) harms arising in the production process of commercial pornography; (2) harms arising in the production of non-commercial pornography; and (3) harms arising in the spy-cam filming of sexual acts or situations to produce commercial or non-commercial pornography.

When most people think of pornography, it is commercial pornography they have in mind. But even when produced for a non-commercial purpose (e.g., for personal pleasure), all sexually explicit materials produced for the fulfillment of sexual desire in a sex-based unequal context are pornography; in fact, many and severe harms happen in the production process of non-commercial pornography. The famous Japanese photojournalist Ryuichi Hirokawa sexually harassed most of the young women who worked or interned at his magazine office Days Japan over decades. This harassment involved not only demands for sex acts but also the filming of naked victims, and revelations of his behavior caused upheaval in progressive Japanese civil society in 2019, most of all, of course, for his many victims (Days Japan investigative committee, 2019 pp. 22-24) As we will see in the next category, harms in circulation, even such noncommercial forms of pornography widely circulating on the Internet, cause harm.

Commercial pornography is a significant sector of capitalist industry, and since the capitalist profit-seeking principle and the male supremacist sex-dominating principle combine in this field, as with prostitution, it continues to produce vast and longstanding harms for society. The harms in production category further divides into the following three subcategories.

Harms in which a naked victim or sexual act is coercively filmed or photographed by another person(s) through illegal or violent means such as assault, battery, threat, or fraud, or under the circumstances, making refusal difficult-for example, out of the necessity of debt repayment, contract fees, psychological pressure, the abuse of mental confusion or embarrassment, being caught by surprise, inducement by family members or intimate partners, or through the abuse of power by people in positions of authority (e.g., an employment relationship in an office).

A second harm of pornography's production arises when a victim has agreed to pornography filming, but the acts demanded over the course of filming are different from what was agreed to in advance or what was contracted, or the contract agreed 
to in advance was so vaguely written that the victim was able to be coerced into unwanted sex acts, or even when the sexual performance demanded in the course of filming was not different from what was agreed to in advance or contracted, the actual acts exceeded expectations or an individual's capacity for endurance, and explicit refusal was ignored.

A third harm of production arises when, even if the performance demanded in filming corresponds to a contract agreed to in advance or the performance is consensual, when this performance has a character that seriously violates or threatens personhood and dignity, or safety and health (including reproductive health), or integrity and respectability (e.g., SM, beating and abusing, vomiting and spitting, scatology, sexual exposure, internal ejaculation, oral sex and oral ejaculation, anal intercourse, sexual abuse with instruments, sex with many persons, choking and suffocating, bestiality, and so on), harm still exists.

The harms of the above-mentioned three subcategories are equivalent to MacKinnon and Dworkin's "coercion into pornography," which is a serious harm of pornography frequently arising in recent years in Japan.

Next, we present some concrete examples from Japan of these production harms of commercial pornography. To begin with, we consider an example that reflects the harms described in category (a) in the immediately previous section, categorized under the description "harms in which a naked victim or sexual act is coercively filmed or photographed by other person(s)."

This was a case in which a victim's boyfriend consulted with APP staff after an incident that occurred in January 2002. His girlfriend needed money at the time through having lost her wallet, and was offered a day job by an acquaintance. This job required her to wear a nurse's costume and be photographed. She was told to wait at a train station, and a man picked her up and drove her to a condominium building. As soon as they entered a room of the building, however, where there was nothing but a large bed, the man's attitude towards her changed, and he told her they would be filming pornography. Then, several men suddenly came out from the back of the room and violently surrounded her. Her boyfriend told the story of what then happened to her, as follows, in a weekly magazine, after having approached APP.

\begin{abstract}
At first the guys sweet-talked her with assurances that her face wouldn't be filmed and told her she'd gone too far to turn back now. When she continued to resist even after these verbal encouragements, one of the men pointed a knife to her groin and asked what would happen if he stabbed her with it. In other words, she was threatened with murder for not going along with what they wanted to do. She's since asked me many times, "do you know what it's like to think you're going to be murdered? It's a fear that can't be put into words." She couldn't escape from that room. In the end she was gang raped and brutalized over a period of six hours. She was tied up and raped by multiple men. She was forced to urinate and defecate in front of them, and they stuck their hands and fingers in her anus. This made her scream.
\end{abstract}

Throughout the ordeal, they had cameras rolling, and every second of the gang rape was recorded in detail. The victim fell into a dazed state, and once filming was over the men threatened that they would send the footage to her workplace if she told anyone what had happened. They then gave her around one thousand dollars. She took the money in a state of confusion and left the apartment building, but then went 
to sit and cry on a riverbank, where she threw the money into the water. She began to develop symptoms of PTSD three months after the incident.

Afterwards, she tried everything possible to make herself feel better. She spent money like water-she used up all her tens of thousands of dollars of savings. She began drinking far more than usual, and developed bulimia. Anti-depressant medication has absolutely no effect. Sometimes when we chat her mood will change in a second, and she'll fly into a rage. She'll tell me I'm just like those guys. She's not like her old self at all.

He took his girlfriend to see a psychiatrist, and she was admitted for treatment. But while she was an in-patient, she attempted suicide by cutting a vein in her groin area. She afterwards told him, "I did what I was told when I thought I was going to die, but now I wish I'd let them kill me." He reflected on the level of suffering she was experiencing to make her feel that way. He concluded his interview with the weekly magazine in the following manner.

People have no idea of the severity of harm victims experience, the distorting effect it has on their lives, and the time it takes to recover. It's not just the victim's life that is affected, but the lives of people around them too. Family members, friends and lovers, too, feel like they've lived through the rape. I want people to know that crimes of this magnitude are happening here in Japan right now.

Unfortunately, this example is just the tip of an iceberg of similar crimes waged in Tokyo. This fact was later confirmed when a spin-off organization of APP members began operating in 2009 to offer outreach to victims directly. PAPS continues to be approached today by many such victims with similar experiences.

The next example shows that, even without explicit violence or assault, coerced filming can be orchestrated through penalty breach charges, psychological pressure, or marathon "persuasion." By using these means, pornographers make victims believe they have no choice but to accept filming. As a result, victims may sometimes agree even to contracts for the filming of pornography, whether agreed to orally or in writing, but these contracts are not based on full knowledge. These means are frequently used in the process of filming pornographic videos sold in Japan.

For example, Honoka, another victim, was once one of Japan's pornography industry's most popular actresses. In her autobiographical book The Cage she confessed, though, that her filming debut was based on fraud and intimidation, including the threat of penalty charges. She closed a contract (though an oral one) with a talent agency to be filmed in a swimsuit, but when she went to the filming set, she found that she was the object of shooting: the filming was not of her swimwear but her naked body. She knew there was a world-renowned photographer, and many shooting staff on location, so it was simply impossible for her, a young and unworldly woman, to reject the shooting. Thus, she was forced to become a photographic subject of nude pictures under such circumstances. After that, it was pornography filming that the agency offered as her next job. She attempted to refuse but was threatened with contract breach fees of the equivalent of sixty thousand dollars. As will be later discussed, these fees are illegal in Japan. She had no choice but to comply: "All I could think about was the impossibility of escape...In the end, I just became the porn-star known as Honoka" (2010, p. 17). 
This practice of pornographers in Japan threatening victims with breach of contract fees if they refuse filming is also seen in another example. An incident occurred in 2014 that eventually brought the problem of coerced pornography filming to public attention in Japan through its widespread reportage in the mainstream media and eventual tackling even by the government. The incident involved a victim who was approached in high school by a recruiter at a train station. He told her he was recruiting for entertainment industry roles, and she believed him. But he had targeted her for a genre of Japanese pornography in which underage girls are filmed in underwear or other skimpy clothing in sexualized poses. Once the filming was over, the victim, Midori (pseudonym), told the man she wanted to quit, but she was threatened with contract cancellation fees of the equivalent of ten thousand dollars. As a result, she was coerced into appearing in many more films. Then, once she reached age 20 , which is Japan's age of majority, she was coerced into pornography filming. Again, she tried to refuse, and, again, she was threatened with cancellation fees that stopped her from quitting.

On the first day of pornography filming as an adult, she was gang-raped, and this scene was filmed. After this experience, she signed a contract that included agreement to pornography filming. She was so distressed by the pornography filming, which was her first sexual experience, too much space that she was in no psychological condition to refuse to sign. This signed contract led to continued filming thereafter. Midori again tried to get out of filming after her second appearance in pornography. Again, this time she was told cancellation fees would amount to the equivalent of one hundred thousand dollars if she did not appear in another nine films. The financial threat had ballooned 10 times. Unbeknownst to Midori, behind her back the talent agency and pornography production company had contracted another 10 films. Midori faced the looming prospect of the next date of filming.

In a state of desperation, she emailed PAPS after finding the organization's website. A PAPS staff member consulted with her the following day. Given the looming filming date, they decided to approach the police. They placed a phone call to Midori's agency informing it she would no longer accept any jobs involving pornography filming. In reaction to this, an agency representative turned up at her house and forced his way in. Police then attended, but, astoundingly, they suggested to Midori a "compromise" solution whereby she would appear in just two more films.

Following this, Midori formally approached a lawyer, and a letter was sent to her agency informing them of her wish to dissolve the contract. But the agency did not accept this withdrawal, and, in retaliation, brought a civil suit against her for the extraordinary sum of the equivalent of two hundred and fifty thousand dollars. However, in September 2015, the Tokyo district court set aside the claim and ruled that contract cancellation is the legitimate right of people subject to unwanted sexual demands. In the end, the plaintiffs withdrew the civil claim and launched no appeal, so this decision still stands today. After Midori won this case, she released her diary from the time she was in the industry, and it included the following passage.

I appreciate beyond words the help I got from PAPS and my lawyer, and from my family and friends. I first came across PAPS when I searched the internet for information about pornography appearance cancellation fees. Until I consulted with PAPS, I thought I was totally bound by the contract, that I had no freedom to act differently. I felt scared for my safety at the possibility of going against what my agency and the production company were telling me to do. There wasn't anyone I could talk to; I just spent all my time worrying. I felt 
like dying. Even when I would ask them to stop during filming because my vagina and genitals were hurting, everyone would just look at me blankly and tell me I had no choice but to continue. Of course, this response from agency and production people was predictable, but even the director and female make-up artist ignored my pleas (Bengoshi dot.com News, 2015).

Because this case attracted widespread media attention in Japan, and Midori's lawyer succeeded in spreading information about the case, it ended up being a case that changed Japanese society's face. Problems of coerced pornography filming that had been previously ignored were picked up in Japan's mainstream media, television broadcasts, parliament, and even by the ruling cabinet. National and local governments drew up concrete measures to tackle the problem. Thanks to Midori's bravery in approaching PAPS, and the full-hearted response of PAPS members and her lawyer in offering help, Japan has seen wholesale changes in its society.

Other survivors of coerced pornography filming began stepping forward after seeing Midori's case. One of these survivors was Hoshino Asuka, who was a popular pornography "star." On her online blog on 21 November 2016, she disclosed that, over six months of brainwashing and manipulation, she had been coerced into appearing in her first pornographic film. Over the next three years, she was coerced into making many subsequent films.

Hoshino was initially involved in nude and sexualized photography for publication in titillating "girly" magazines orientated towards Japanese male youth. She became well-known through these publications. According to Hoshino's blog posts, she was approached by a man introduced by her talent agency who used good-guy-bad-guy tactics on her over six months to brainwash her into pornography filming. One day, Hoshino attended a set where she had been hired for nude modeling but arrived to find the set was a pornography studio. This was even though the hiring contract she had signed said not one word about pornography filming. She consulted with police and lawyers at the time about the contract she had signed, but they told her such fraudulent things were not done in the industry anymore, and so she felt like she had overreacted and decided to stay silent. It wasn't until 2015, when the issue of coerced pornography filming was taken up by the mainstream media in Japan, that she began to write of her own experiences on her blog. Because of the pornography filming she subsequently endured, she developed anorexia, panic attacks, depression, and social anxiety. She was debilitated with these conditions for three years, and, even now, she suffers trauma that makes her fear men and sexual relations (Bengoshi dot.com News, 2016).

There are a growing number of survivors of pornography production in Japan speaking out- for example, the YouTuber Kurumin Aroma who, in 2011, as a university student, was recruited in Shinjuku for "modeling." As a university student, Kurumin was keen to forge a singing career, and the recruiter told her that nude modeling would help with this, so she was persuaded to go with him. But when she was allocated assignments, she found they were for pornography in addition to nude modeling. Aroma did not want to go ahead with these assignments, but she was persuaded by the idea they would lead to singing work, and so she was coercively "persuaded." Then she ended up appearing in pornography that led to nothing but harm. She suffered as a result and did not want to admit to her experiences but decided to come forward as a survivor because she hoped her actions would help others. Kurumin publicly disclosed her story and continues today to speak out as a survivor (Bengoshi dot.com News, September 2016). 
There are other examples of survivors in Japan recently coming forward to disclose their experiences. For example, Matsumoto Ayase, in 2016, was working as a freelance television announcer at the time, as well as YouTuber Kosaka Kino in 2019. In Matsumoto's case, in 2010, she was targeted on the street by a man who pretended he needed her help as a university student. As a result, she was detained in a van where she was made to lick a man's penis as if she was sucking a lollypop. This filmed recording was then used as a lead-in to a pornographic film that went on sale. Matsumoto went on to work in television, but, a few years later, the footage was reported in a gossip magazine. As a result, she was forced to give up all her television work. She has said of this time that "I couldn't even swallow my food, and spent every day crying. I thought of suicide" (Bengoshi dot.com News, 2016). In Kosaka's case, in 2010, she was asked to fill in a survey by a man on the street, and, as a result, similarly came to be detained in a van from which she could not escape. In the van, she was forcibly filmed participating in pornographic sex acts (Yamashita, 2019).

As shown in Kurumin's experience described above, the pornography industry commonly tricks women into filming based on promises of modeling or entertainment industry work. To capture data about this situation, Japan's cabinet office ran an Internet-based survey in September 2016, whose results it released in February 2017. According to these results, of 197 respondents of a total of 2575 people who had the experience of signing a filming contract, 57 testified to being pressured to undertake sex acts they had not been told about at the time of signing the contract or to which they had not agreed. Of these, 17 respondents had acquiesced to the pressure and had been filmed in pornography. When asked why they acquiesced, respondents wrote, "because I'd signed a contract agreeing to the acts," and "because they threatened me with exposure of films/photographs they'd already taken." Further, another 60 respondents to the online survey answered that they had been forced into sexual filming or photography with neither consent nor contract (Bengoshi dot.com News, 2017). This is the first survey of its kind undertaken in Japan, and it revealed one dimension of the serious problem of coerced pornography filming in the country.

The next two subcategories of harms involved in pornography's production, described in items (b) and (c) above, apply respectively to situations in which, even when a victim has consented to the filming of pornography, they are forced into nonconsensual or not-contracted acts, or violent, dangerous, and violating acts in the process of filming. These harms frequently happen in the production of pornography, and more often since the mid-1980s because of the trend to produce more violent and more "real" footage with new kinds of so-called "reality porn." Its archetype is a series of violent, pornographic films titled Nyohan [Women-fucking] (produced between 1990 and 1991) directed by Baksheesh Yamashita. This series of pornographic films was made after almost no information was given to victims about what would be filmed. Further, the women were forced into all manner of abusive and degrading acts to film them exhibiting "real" reactions of fear and response. This was a theme of the film series and its selling point (see Yamamoto, Norma \& Weerasinghe, 2018).

The opening scene of one film in the series shows a woman surrounded by unattractive, lecherous men. When she exhibits some resistance to their actions, several "strongmen" enter the scene and inflict violence on her to "punish" her for this reaction. The men repeatedly rape her, but they also inflict various types of violence on her, such as beating her around the head, hitting her in the stomach and back, kicking her, and dragging her around by the hair. They repeatedly spit in her face and force her head into a toilet. When the woman shouts out in protest at this treatment and attempts to run away crying, they catch her and beat her brutally till she stopped, and 
then they show prolonged footage of her whimpering. This kind of torture pornography is praised as "progressive" and "radical" by intellectuals and liberals in Japan, including the Asahi Shimbun-produced AERA magazine. In the case of this violent, pornographic series, the victim was unable to report to the police, and the perpetrators remained untouched by the law.

Moreover, a range of subsequent films were produced and sold in Japan based on the model inspired by this film series involving the same techniques of violence and torture. Eventually, however, one of these subsequent series became the subject of police and legal intervention. Specifically, a case known as the Bakky case involved Japan's worst post-war filming of violent pornography.

In June 2004, the pornography production company Bakky Visual Planning (launched in 2002) produced a film in which a woman was subjected on set to violence by a group of men. The violence was so severe it resulted in a punctured rectum and other injuries requiring four months of treatment. Upon being discharged from the hospital, the victim lodged a complaint with police in October 2004, and eight men were arrested in December. But these men were not prosecuted, and, apart from one man who was charged on another count, all were released without charge. However, the company's violent practices came to be known about more widely because of this case and police began to keep watch on it. As a result, its staff ended up being charged, prosecuted, and tried in court.

In the filming of an earlier Bakky Visual Planning September 2004 series called "water torture," a woman was subjected to violence over a period from $1 \mathrm{pm}$ to $9 \mathrm{pm}$, and had her head repeatedly forced into water to cut off her breathing, and sustained severe injuries, including bruises and sprains throughout her body, including whiplash. According to the prosecutor's court brief:

The victim was subjected to violence even after she had passed out, and her life was endangered. Since the incident she has been unable to leave the house and has become anxious to the pointing of believing that someone will come and try to kill her. She has trouble breathing just at the sound of a raised voice, and she now has serious problems of social anxiety (ESPIO!, 2005).

In this case, the victim approached police the following year, and, on 31 March 2005, a total of seven men were arrested and charged, including the film's director, actors, and cameraman.

Further, in the second film of the "water torture" series released in November 2004, a victim was beforehand intimidated with the choice of either "having sex with twenty men eighty times," or "being dunked in water." Before filming, staff assured her that if she chose dunking, she would not be harmed, and they would stop filming whenever it got too difficult. But, when filming started, none of these assurances were delivered. There was no let-up in the violence inflicted with male performers, and she was dunked to the point of drowning in a pool on set many times. She appealed to the director to stop because she thought she would be killed, but he ignored her. She was brought close to drowning in water, forced into a box into which water was funneled, strung upside down, and had her head repeatedly forced into a bucket of water. In the end, her head smashed a mirror in the bathroom where she was being raped, and a broken fragment of the mirror sliced deeply into her ankle, causing massive blood loss. An ambulance had to be called. The victim sees this serious injury as a piece of "luck in the midst of misfortune" because it meant filming finally stopped. Her torture had continued for 12 hours, from 8.30 am to $9 \mathrm{pm}$. She now lives life in a wheelchair 
and has a severe fear of water that prevents her from taking a bath (see Amaki, 2007; Amaki, 2008).

A few brave victims among the many victims of this kind of violent pornography produced in Japan have stepped forward to lodge complaints. This has resulted not only in the arrest of their perpetrators but also in their prosecution and trial. Moreover, nearly all have received custodial convictions at trial. It should be noted that Bakky Visual Planning's executive director, who did not attend the set where the violence was inflicted, was also sentenced to an 18-year term of imprisonment. This action was finally taken against violent pornography producers, whose products were left unaddressed for so long, and was the first time in Japan that the harms of pornography's production were subject to legal judgement, even if this judgement did not result in legislative action against the country's pornography industry.

Filming and recording technology are highly developed these days, so even an individual can produce pornography. Many serious harms happen in this process. These can be categorized as the second kind of production harm: harms arising in the production of non-commercial pornography, with three sub-component harms, as follows:

a. Harms in which a victim is sexually violated at the same time this violating act is shot or filmed;

b. Harms in which a naked victim or sex acts are unwillingly photographed or filmed by a husband, lover, father, or brother; and

c. Harms in which, through fraud, threat, or psychological control, a victim is coerced to photograph their own naked or semi-naked body and to send the resulting selfie(s) to an offender.

A typical example of the harms in category (a) above is a rapist filming his crime and/or victim to later repeatedly enjoy it by himself or to silence his victim by fear. Serial rapists tend to do this, but today when almost everyone has mobile phones that can be used as personal filming equipment, sex offenders shoot their criminal acts and victims' violated selves. For example, in Japan, journalist Shiori Ito won a civil case against her sexual attacker in 2019 in relation to crimes described in her 2017 memoir that she suspected he had filmed on his laptop computer. The perpetrator, Noriyuki Yamaguchi, was a former Washington bureau chief of the major Japanese broadcasting company TBS. In 2015 he spiked Ito's drink and escorted her semi-conscious back to his hotel room where he raped her (see Ito, 2017, p. 49). In this case, victims suffer harm not only through sexual violence but also the additional harm of having the violence filmed. The filming of a victim being raped or in the aftermath of rape perpetuates the damage initially done, and this perpetuates their suffering and pain. When victims are forced to imagine their offenders repeatedly watching the film or photographs, they may feel they are repeatedly being raped. On top of that, imagining the possibility of the crime being used in various ways, victims can descend into fear, because the footage can be uploaded to the Internet, or edited as pornography and distributed. Or a perpetrator may circulate recordings among a victim's company/school or among her acquaintances.

A famous example of a perpetrator taking spy-cam footage of his sexual violence occurred in 2014 when a 40-year-old male oil massage shop manager was arrested and prosecuted for raping and sexually assaulting female customers. He filmed his criminal acts using a hidden video camera located in his shop. After he was arrested, his attorney urged victims to withdraw their charges, even with no money paid in outof-court settlements, in exchange for disposing of the videos. One of his victims later confessed her pain when the deal was proposed: 
I felt extreme fear like my life was over...The proposed condition of no settlement money meant, I believed, that they had not recognized me even as a victim...I had to watch the video in which I was raped. After watching it and going home I suffered severe headache. I could not sleep due to nightmares that night, so I was forced to take time off work the next day (Mainichi Shimbun, 2015).

The harms described in (a) immediately above also include harms in which samesex acquaintances forcibly film a naked victim or sex acts as a bullying or punishment technique in schools or workplaces or within any type of institution. In this case, not only do women become victims, but men frequently become so, too. These acts are forced on them not to gratify offenders' sexual desires but to impose deep humiliation and fear on the victim and to increase the effect of punishment and submission.

There are many news stories reporting this kind of harm, including an incident from 2014. According to a news article of the time, four male students at a public high school stripped their male classmate bare, kicked his bottom, and filmed these acts with a smartphone after a school swimming class. The following month they uploaded the movie to a video-sharing website. The school found out about the incident when it was tipped off by an anonymous informant a few months later (Yomiuri Shimbun, 2014).

The category mentioned above (b), coerced appearance in pornography filming, is limited to that by strangers. Still, this coercive filming can also be done by a husband, lover, father, or brother in a private place like a home or motel. As the development and popularization of video cameras and VCRs early on made the private production of pornography much easier at home or elsewhere, this became a form of domestic violence and date rape.

In the category (c) above, described as harms in which, through fraud, threat, or psychological control, a victim is coerced to photograph their own naked or semi-naked body and to send the resulting selfie(s) to an offender, victims are mostly underage girls. They are manipulated, threatened, or cheated by adult men to photograph their own naked or semi-naked bodies and are induced or coerced to send the selfies to the men by e-mail or social media. In case that these victims are under 18 years old, as the incidents are cases of child pornography, offenders are arrested and punished, so we can know of their harms through newspaper articles reporting them. For example, a Japan Self-Defense Forces member was arrested in November 2019 for loan-shark activity offering women loaned money on the condition they would send photographs in their underwear as "collateral" (TBS News, 2019). But if the victims are over 18 years old, we have no law against the acts themselves. Offenders sometimes induce or coerce women to self-photograph by making use of their economic plight or other vulnerabilities.

\section{Harms of Spy-Cam Filming}

Harms of spy-cam filming arise in both commercial and non-commercial contexts. In today's Internet age, non-commercially filmed spy-cam footage can easily be uploaded to pornographic websites and turned into commercial material. In an incident reported in July 2019, for example, a 30 -year-old Osaka man filmed sex acts with a woman he met online, and uploaded more than 200 clips to a site online from 2013 to earn revenues of around eight-hundred thousand dollars (Kobe Shimbun, 2019). There is little reason to differentiate between the two kinds of secretly filmed footage, and so we discuss them in combination here. 
So-called "spy-cam filming" is a significant genre of commercial pornography. When we search products listed on Amazon Japan's site using the keyword tousatsu (spy-cam filming), the number of hits is more than 10,000 (as of December 2020). Because the number of hits produces more than 10,000 results, no higher number can be displayed, so the real number of products on sale is unclear. When researching them in August 2010, the number was no more than 7,000. For comparison, when searching the keyword chikan (sexual groping), more than 6,000 hits arise; when searching the keyword rape, there are more than 9,000 hits. These comparisons show how big the market for "spy-cam filming" is in Japan. Many people believe these videos are fake, but they are wrong. As we know from an old newspaper report from 2002, a manager of a pornography production company who was arrested for organizing a female gang of spy-cam filmers to produce and sell many spy-cam videos said in a deposition that around $40 \%$ of "spy-cam filming" circulating in the commercial market was "fake," but the rest was authentic. "When connoisseurs watch them, they discern the authenticity of them. So, we had to run the risk of secretly filming," he said (Tokyo Shimbun, 2002).

While spy-cam filmed pornography is a significant genre of the commercial pornography market, it is also produced in large volume to gratify individual perpetrators. The miniaturization and sophistication of spy cameras now allow anyone to secretly film anywhere-changing rooms, public bathhouses, public toilets, motel rooms, private rooms, on the street, in schools, in the workplace, and on public transport. A complete stranger can secretly put a spy-cam in a public place like a toilet or changing room, and a partner, brother, or any other family member can secretly film or photograph a victim's naked or semi-naked body while bathing or changing clothes in the home. Further, a sex-buyer can order a woman for prostitution through an escort agency and secretly film her body or sex acts. Among recently reported incidents in the Japanese media, in December 2019 a man in his 40s ordered an outcall escort prostituted women to come to his house where he filmed her in sex acts (Kobe Shimbun, 2019). Another incident reported in June 2008 involved a man in his 30s having installed spy cameras within the walls of women's toilets in a public park and secretly filmed mainly junior-high or high school girls for seven years. Police confiscated hundreds of SD cards and DVDs from his house. In this incident alone, the number of the victims seemed to have amounted to several hundred (Kyoto Shimbun, 2018). Because Japan doesn't have national legislation against spy-cam filming, police clamp down on the crime as a nuisance act in public spaces under local nuisance prevention ordinances. There is no law requiring deleting materials shot by spy cams, so advocates are now campaigning in Japan for a criminal law against spy-cam crimes (see Bengoshi dot.com News, 2018; Mainichi Shimbun, 2018).

\section{Harms Arising Through Pornography's Circulation}

Next, we deal with the second major category of pornography's harms: harms in circulation. Commercial pornography involves selling and circulating the produced materials. In this sense, harms of production closely combine with harms of circulation. But it is possible to distinguish between them. For example, in the case of harms described in the category of harms arising in the production process of commercial pornography, when a victim is coerced to appear in pornography by force or fraud, or when they are filmed with a spy camera, these crimes by themselves represent a severe violation of human rights.

On top of that, when the materials produced by these crimes are sold or disseminated in public, this represents an additional and grave violation of human rights. And, 
even if the materials are photographed or filmed with a person's agreement, their non-consensual distribution or dissemination constitutes distinct and serious harm. Thus, it is necessary to distinguish them, even while, in real life, the production and circulation harms of pornography are often inseparable.

These "circulation harms" can be further broken down into three subcategories.

a. Harm that victims additionally suffer when commercial or non-commercial materials arising from various harms of pornography (such as coerced appearance or spy cam filming) are circulated or disseminated.

b. Harm that victims suffer when materials, including footage or photographs of a naked victim or sex acts, even if they had consented to their filming, are non-consensually distributed or disseminated.

c. Harm that victims suffer when facial photos or caricatures are used to produce fake sexual photos or caricatures and are published or distributed in magazines, newspapers, or the Internet (deepfakes). This can include publication with a victim's identified name, and use of aspects of their career in a sexual and sexually demeaning context.

In the case of pornography's harms, different from other sexual harms, the recording of the harm remains in a physical or digital form. Therefore, human rights violations in the production of pornography cause an additional violation when the harms become recorded materials that are distributed or disseminated. Today, in the era of computerization and the Internet, you can infinitely copy the digitalized materials with a simple process, and easily distribute them worldwide. Considering that footage in which victims are sexually abused, raped, or tortured, or materials that are produced through spy-cam filming, are eternally exposed to countless people, this harm might exceed even harms of production.

The earlier mentioned victim Midori wrote in her diary that:

[e]ven when the court case is over, many problems will remain. Once something is picked up in the Google search engine, or released to a video hosting site, it tends to stay on the internet forever. You can't forget about it even if you want to. This will be a problem I have to deal with forever. I'll never know when, where and who will find out about the videos. The idea of having to live with this burden is difficult to accept (Bengoshi dot.com News, December 2018).

Many of the harms in relation to which victims consult with PAPS involve this type. PAPS members must therefore negotiate with Internet service providers and request pornography companies stop selling DVDs. They also contact hosting websites to delete them. This is an arduous task, and companies do not necessarily respond to requests.

Furthermore, when these materials are edited and distributed as commercial pornography, an additional harm results: harm in which they are accepted by the public as produced through voluntary consent rather than through coercion. On the front cover of DVD boxes and in Internet thumbnails, photographs showing victims smiling may be used or even spliced into the footage. But these scenes might be shot before full-fledged shooting begins or despite a victim's trauma. But consumers buying the DVDs will believe they were produced with the consent of the victim.

Further harm of pornography's circulation occurs in the case of intimate partners who, even if one of them has agreed to film sexual photographs or movies, distribute 
or disseminate materials without permission. Alternatively, harms can arise in cases where a third party obtains them one way or another and distributes them without permission. The phrase revenge pornography has come to represent this typical pattern of harm in which a man, often out of revenge for a relationship ending, distributes (or uploads to the Internet, or hands to the media) his ex-lover's sexual photographs or movies which were shot when dating her.

The murder of a high school girl in Tokyo in 2013 drew public attention to this problem. An offender aged in his 20s, out of revenge for having the relationship ended by the girl he was dating, uploaded her sexual photographs and movies in large volume to the Internet and eventually sneaked into her house to stab her to death with a knife. This incident led to the enactment of a law banning the distribution of private sexual pictures and footage of others without consent (the law is commonly known as the revenge porn law). Although this law initially had the purpose of clamping down on revenge pornography, it can be and already has been adapted to cases in which private sexual pictures or footage are distributed without permission because this law on its face places a ban on the non-consensual distribution of all private sexual graphics, including ones of spy-cam filming. The law has already been applied in one instance in which a man secretly filmed 300 people using a unisex toilet in inner-city Tokyo over a one-year period. He uploaded the footage to a spy-cam footage website and earned roughly a quarter of a million dollars. After being arrested for spy-cam filming under Japan's public nuisance regulations in October 2018, he was re-arrested for the uploaded footage under the provisions of Japan's revenge pornography law. He was re-arrested for spy-cam crimes again in July 2019 after having received a suspended sentence for the original crimes (Higashi Supo Web, 2018).

Further harm of pornography's circulation arises when a victim initially agreed to both filming and pornography distribution and sales (as in the case of commercial pornography), but, after that, over time, came to feel disgusted about the continuing distribution or sales of the materials, even as the materials continued to be distributed or sold. Even when someone participates in the filming of commercial pornography by choice and then also agreed to sales, they can then have a change of mind or change of situation, such as the beginning of a new relationship, or mainstream job, birth of a child, a reaction to pornography coming to light among family members or friends, or feelings of remorse about the footage. However, if they yield profit, production companies and distributing agencies usually continue to sell the materials in disregard of the wishes of victims.

Under current contracting practices in Japan's pornography industry, performers' copyright and publicity rights are handed over to production companies. So, in addition to the videos in which someone has directly agreed to perform, it is common that footage is repeatedly re-edited and re-commodified as different videos, such as in the case of specialty compilations. Alternatively, the footage can be unilaterally bought by overseas websites like Caribbeancom.com or Pornhub. The footage is then broadcast from these sites, and sometimes without the original blurring of genitals, as required in the case of pornography produced in Japan (Bengoshi dot.com News, August 2019). As a result, the harm of the original filming continues into perpetuity.

After problems of coerced pornography filming came to light in Japan, the pornography industry established an organization called AV Human Rights Ethics Organization in 2016. It announced the organization would act upon requests from victims for the discontinued sale and Internet distribution of pornography produced more than five years prior. While this measure represents a small improvement in current conditions, not all pornography production companies are part of the AV Human Rights 
Ethics Organization. The requirement that five years must have elapsed since production is excessively long. Also, the organization cannot act to take down materials distributed via overseas-hosted websites. Effectively, the problems the organization was established to address continue, as before.

A third harm arising from pornography's circulation is equivalent to defamation through pornography in the MacKinnon-Dworkin classification. Today this harm has become an explosive epidemic as the Internet spreads to every corner of the developed world, and synthesizing technologies for images becomes highly developed. Famous women tend to be its targets. For example, in the case of a court decision recorded in July 2016, famous Japanese actresses such as Haruka Ayase and Satomi Ishihara filed an action for damages suffered by the publication of their fake photos, which involved composite facial photos overlaid onto elaborately drawn images of their naked bodies in an entertainment magazine. They won the case (Bengoshi dot.com.News, July 2016). Such pornography collages target celebrities and female politicians and activist women to demean and silence them. Rapid technological progress is being made not just in filming but also in cinematic editing, which now means celebrity faces can be superimposed onto sex scene footage as if the person had been filmed. This is called deepfake pornography, which is becoming a problem internationally.

\section{Harms Arising Through Pornography's Consumption}

Consumption harms of pornography can be further categorized into two sub-categories of harm.

1. Harms in which you are forced to watch pornography or imitate pornographic acts at home or at work.

2. Harms in which you suffer sexual assault or other sexual abuses from someone directly affected by pornography.

The category of harms arising during pornography's consumption is roughly equivalent to the forcing pornography on a person harm of the MacKinnon-Dworkin classification. These harms can be further categorized in the following two ways.

a. Harms arising when victims are forced to watch pornography at home against their will or is exposed to unwanted pornographic items (such as nude calendars or adult DVDs) daily at work or at home. When this harm arises at work, it represents an environment-type of sexual harassment. When it happens at home, it represents a form of domestic violence. Also, when children are forced to watch pornography, it represents, in of itself, a form of child abuse, and furthermore plays a role of luring children into sexual acts. Sexual abusers expose children to pornography to dissuade feelings of resistance or repulsion to pornography. In this case, it directly leads to the harms of (b) below.

b. Harms suffered when behaviors imitating pornography are enforced at home or within an intimate relationship by a husband, lover, or brother. Customers imposing such acts on women in places where they are bought for prostitution can be included in this category of harms. Customers of the sex industry often feel free to impose perverted sexual acts on women bought for prostitution that they are unable to demand of intimate partners.

Researchers have clarified the causal relationship between repeatedly watching pornography and perpetrating sexual violence. In the MacKinnon-Dworkin classification, this is named assault or physical attack due to pornography. Pornography often takes sex crimes and violence as its theme, including crimes like rape, gang rape, sexual harassment, sexual assault, spy cam filming, incest, torture, sexual exposure, de- 
tention/abduction, child abuse, bullying, punching, and kicking, and choking, and present them as enjoyable forms of sexual entertainment. Since pornography imprints on a circuit of intense physical pleasure, in terms of sexual desire, it effectively dominates male sexuality (and sometimes women's sexuality, too). This woman-hating fundamentalism, which is deeply internalized and sexualized in men's minds and bodies far beyond mere ideological conviction, converts numerous men who are dominated by it into terrorists. In every corner of our society, some terrorists do what pornography suggests. From sexual objectification through molestation, sexual harassment, and rape, and sexual torture, and sexual murder. The results of these actions produce an even greater volume of "sexual violence due to pornography."

No form of "expression" openly admires and exalts crime as pornography, let alone against a group so oppressed. Indeed, there are crime or detective novels, but most of these describe crimes as impermissible wrongs and so preordain that perpetrators will be arrested and punished. They base themselves on a sense of justice felt by people and tune into this. Is there pornography that presents such violence against women as truly impermissible crimes? Is there pornography in which perpetrators are arrested and punished? These possibilities are inconceivable, precisely because pornography, by definition, exists as sexual entertainment. It describes all manner of violence against women as not only socially permissible but also supremely sexually pleasurable. It does not base itself on a sense of justice. On the contrary, it breaks down any sense of justice, any sense of equality, any sense of humanity and expels a whole group of women from the domain of freedom, justice, and equality. It is necessary to stem the spread and pervasiveness of materials that incite violence against a socially vulnerable group and which cause real violence and assault.

Akiyoshi Saitou, a Japanese psychiatric social worker with professional experience working with more than 150 sex criminals, suggests that repeated watching of pornography powerfully motivates offenders to commit sex crimes. Although he especially emphasizes a causal relationship between watching child pornography and conducting child molestation, the same relationship can be established between watching adult pornography and perpetrating sex crimes against adult women. Furthermore, we must remember that one sex offender can victimize hundreds of women and girls. Saitou described his experience:

When at a local prison I gave a speech in front of the prisoners serving their times due to sex crimes, I told them about the research of an American researcher, which shows that the number of victims of one offender in his lifetime is 380 on average. In the audience there were some men who had repeatedly conducted sex crimes against children. One of them told me: 'You said $380 \ldots$... I did more than three times that.' Other child sex abusers nodded in vigorous agreement.

Saitou further suggests that, from his interviews with offenders, "child pornography was the trigger for child sex offending" in 95 percent of cases (Abema Times, 2019).

We know from newspaper reports that there are many cases in which criminals were stimulated by rape pornography or spy-cam pornography to perpetrate similar crimes. A 35-year-old Japanese man arrested in September 2017 for sexually assaulting a woman at knifepoint attested to have developed an interest in rape "after watching rape pornography online." He further admitted to having perpetrated similar sex crimes against two other women (Nittere News, 2017). In another case in June 2016, a 37-year-old Japanese man was arrested for sexually assaulting six young primary 
school girls and testified to police that he had learned of such behavior from watching child-themed pornography since his 20s developed a sexual appetite for young girls (Sankei Shimbun, 2016). In a further case, on 17 December 2015, a large volume of choking-themed pornography was found in the house of a Japanese man who had strangled a 17-year-old girl to death. He testified that the materials had led him to develop an interest in choking and that he had committed the crime partly as a hobby (FNN, 2015).

The likelihood of regular pornography viewers enacting in real life the sex crimes they have been watching escalates in pornography genres like Japanese chikan public molestation and spy-cam filmed pornography. A survey was undertaken in Japan over the months October-November 2002 in relation to chikan forms of public sexual harassment. A graduate student at a university in Osaka surveyed more than 800 graduate students (513 men and 314 women) about public sexual harassment and found that men had experienced the crime at rates of $9.6 \%$ and women at rates of $41.4 \%$. Among male respondents, around $4 \%$ had perpetrated the crime themselves. As many as one-fifth of male respondents expressed an interest in perpetrating the crime (among women, these responses were about 1\% each). The finding compounded this extraordinarily high response rate among the male students; only $5.3 \%$ of those who had perpetrated the crime had not seen pornography of the same genre. The rest had watched it one or more times. Among the male respondents who had no desire to perpetrate the crime, around $60 \%$ had never seen pornography of that genre (Fujita, 2003, p. 35).

\section{The Fourth Form of Pornography's Harms: Social Harms}

Pornography causes damage to specific persons, but, more than that, its widespread existence in society also causes damage to an unspecified number of people (needless to say, mainly women). We call these harms the social harms of pornography. These harms can be further broken down into two subcategories.

1. Psychological harm experienced because of exposure to widely circulating violent pornography (i.e., environmental pornographic harm).

2. The exacerbation of sex discrimination and misogyny because of the widespread dissemination of pornography

Harms arising in subcategory (1) above are those that an unspecified number of people can sustain when they unexpectedly or unwantedly view advertisements, posters, signs, flyers, advertising posters in trains, men's magazines, and magazine covers that display photos or graphics of women's naked or semi-naked bodies, or graphics or drawings highlighting the sexual body parts (breasts or buttocks) of young women. These are called environmental harms of pornography, a social version of the "environment"-type of sexual harassment. In Japan, where comics and graphics sexually depicting young girls are popular, the possibility of viewing something like the materials described is much higher than in other countries. Many foreigners who come to Japan are surprised and perplexed by the sight of such materials in daily life. An early piece of research undertaken in 1999 by a gender research group at Konan University interviewed 59 women living in western Japan, from teenagers to women in their 70s. Of these women, $81-96 \%$ had been exposed to pornography in the form of train carriage advertisements, sex industry classifieds in men's magazines, or flyer advertising for sex businesses. Further, of the 59 women interviewed, 54 (91.5\%) had experienced sexual assault, and of these, 49 (83\%) had been victims of public chikan harassment (Konan University Graduate Gender Research Group, 2000). 
In this case, the harms of pornography are two-fold. First is the harm involving the discomfort and embarrassment of the person who has been incidentally exposed to pornography in a setting where sexual materials are not expected to be present. This harm is remedied even in anti-obscenity laws, which see such cases as matters of public nuisance. Second is the harm relating to the fact the materials are not just sexual but depict women as sexual objects. In other words, they diminish women's humanity and reduce women to an existence that is fundamentally sexual. The second harm of the materials relates precisely to this feature-they are harmful to the discriminatory and demeaning message they fundamentally convey about women. When women express displeasure at the materials, they are not usually concerned about their sexual nature as much as their sexism. In other words, women are worried about, and object to, how sexual depictions and sexualized distortions reduce all women, including themselves, to merely sex or to specific body parts.

Furthermore, in today's world of the Internet, unintentionally clicking on a hyperlink can mean that sexually explicit images or sexually violent graphics can incidentally be seen. That causes mental damage for the unintentional viewer of such images or graphics. This harm is even more significant when the viewer is a victim of sexual assault. And, unfairly and unjustly, victims of sexual violence may be more likely to encounter such images on the Internet unintentionally. This is because, for example, when people targeted for sexual victimization, spy cam filming, or other sexual assaults try to look for information about these problems on the Internet, they find most websites are pornographic ones, such as chikan porn, spy-cam porn, and rape porn. It is not difficult to imagine the seriousness of the harm victims encounter when searching for information about crimes they have sustained. It is undoubtedly hard to imagine a more unjust and dispiriting situation than this one, in which victims come to realize they live in a society that enjoys crimes committed against them as sexual entertainment.

These environmental harms of pornography are still more serious for children. Today most children daily use smartphones or tablet computers, so when searching for something on the Internet, they can incidentally view brutal pornographic pictures or footage or pornographic advertisements. These circumstances in which children are vulnerable to seeing such cruel pornographic images is nothing less than child abuse on a society-wide scale. The message that these materials carry to children is that women and girls exist for men's sexual pleasure. Such a social message becomes a powerful driver directing them towards sexual abuse and the sex industry.

As with the separation of smoking areas as a measure against the harms of cigarettes, zoning regulations for the placement of pornography are generally proposed as measures against pornography's harms. To be sure, we believe that zoning policies are mostly ineffective, as with the separation of smoking areas. For example, pornographic magazines and books are vanishing from the big convenience stores in Japan at the time of writing, partly driven by progressive concerns (Buzz Feed News, 2019; Etcetera, 2019). But this measure is massively insufficient (because the rest of pornography's harms remain untouched), and on the Internet, a zoning policy is hardly workable.

The harms of category (2) above, described as the exacerbation of sex discrimination and misogyny as a result of the widespread dissemination of pornography, are equivalent to the trafficking of pornography of the MacKinnon-Dworkin ordinance classification. Even when zoning regulations for pornography are well-established, not all women can avoid harms, including declines in sex status, aggravation of inequality between the sexes, sexual objectification, and harms arising from the mass 
production of pornography, its widespread circulation, and its mass consumption. This type of harm should not be residing at the same level as harms arising from the circulation of an incorrect ideology in general. The widespread circulation of pornography is different from the mere dissemination of a false ideology. It has an impact far beyond any such level and so brings about declines in women's status through real harms imposed directly.

The structural hierarchy of social inequality between men and women, which has been historically maintained and accumulated for many centuries, turns free-speech "expression" into something more than mere expression. This effect is, of course, common to other forms of racial and ethnic hate speech. But, in the case of pornography, to purvey an ideology of sex discrimination, visual means such as pictures, photographs, and footage are used, and these have a more direct and popularly inciteful effect than strings of letters. Indeed, hate speech directed at other groups also incorporates visual representation (such as posters of Jewish people made by Nazis), and novels are found among pornographic materials. While most hate speech against other groups is conveyed through the written word, the opposite is the case for pornography, which is overwhelmingly a form of sexist propaganda conveyed visually through pictures.

Importantly, in the case of live-filmed pornography real women are sexually used and abused in its production. It is not just that these uses and abuses of women, in of themselves, comprise a practice of sex discrimination, but also the incitement effect of the materials, in using real human bodies, is different from that of other ideological propaganda. It produces an existential and internally felt conviction in men, deep in their minds, that it is permissible to treat real women in such a way, and to do those sorts of things to women, and that women deserve such treatment or delight in suffering it. Pornography socially drags women down to second-class citizenship and hence promotes men's sexual violence against women who are placed in this low status. Inversely, sexual violence incited by pornography maintains women's secondclass status. Thus, pornography is, also in this respect, not only a theory or expression, but also a practice. Further, it is a practice of sex discrimination for enacting a range of acts of sexual violence at the micro-level in its production and consumption and at the macro level in its contribution to enacting a society of violent sex inequality. It therefore comprises a structural practice of sex discrimination.

\section{Harms of the Existence of Pornography}

Finally, we consider the fifth of harm of pornography, harms of existence. Although this is an unfamiliar harm of pornography, the category refers to the phenomenon whereby commercial or non-commercial pornography is produced in one way or another, but not released or disseminated, but, because of its continuing existence in the hands of someone, causes a victim harm. This harm spreads through digital or webbased means, and is fundamentally different from the harms that arise with pornography's production and dissemination. When pornography existed mostly as a physical, concrete product, it was relatively easy to destroy. However, in the twenty-first century, the proliferation of digital media now allows for limitless reproduction of the materials, and their unfettered dissemination. They come into the possession of multitudes of people. This new situation underpins our definition of the 'harms of existence' category of pornography, which must be recognized as encompassing a phenomenon uniquely arising with the quantum shift in technology. As we will see, this category of pornography's harms requires specially tailored legal responses. It can be broken down into two subcategories: 
1. Mental harms in which victims of some aspect of pornography's production harm (for example, coerced filming or spy-cam filming) continue to feel fear, disgrace, and humiliation because pornography produced through such harmful practices of production remains an object of personal consumption in someone's hands; and

2. There are further, more direct harms in cases where an individual is threatened or harassed by a person (above all, an ill-intentioned person) who keeps their sexual photos or footage, whether these materials were produced through harms of pornography production, or not.

Taking the example of the coerced filming of pornography through assault, threat, or fraud, this directly inflicts harm on the person who is the object of filming. This is a form of pornography's "production" harms." When this footage is sold as commercial rape porn, or disseminated through the Internet, a form of "circulation harms" additionally results. Even when not circulated, though, as long as the footage stays in the hands of an offender or consumer, the victim continues to feel fear and humiliation. She experiences mental distress at the thought the materials will be circulated at some time in the future or have already been circulated without her knowledge. This is the case just as child pornography, even if not circulating, continues to cause victims' harm merely through existing as entertainment in the hands of consumers. Pornography produced through assault, fraud, or other violating acts, as with child pornography, keeps producing mental harm through its existence and possession (Tankard Reist\&Bray, 2011).

The harms of (2), above, are different from the harms of (1) at the point that someone who retains sexual photos or footage of an identified person directly approaches, with malicious intent, the victim or their family. That someone (for example, an exlover, ex-husband, or a third party with ill-will) may blackmail and extort in relation to such materials, and this can take the form of direct demands for cash, or for sexual relations, or other forms of harassment. There are many instances of such crimes in Japan where photos and footage are used as a means of extortion. A man aged in his 30s arrested in December 2019 was suspected of nude filming a woman he met on an Internet dating site, and afterwards threatening to publicly release the footage. Using this tactic, he had previously extorted around $\$ 2600$ from two women. During investigation of his crime, police found naked footage of over 100 women in his possession, and the man is now suspected of having perpetrated other crimes (FNN, 2019).

\section{Prospects for a New Legal Strategy}

In this final section, we consider three different legal approaches to pornography, and then describe our own preferred strategy. First is a comprehensive legal approach addressing all harms of pornography by addressing pornography itself (i.e., the MacKinnon-Dworkin Ordinance). Second is an individualized legal approach addressing specific harms by establishing special legislation against particular harms of pornography (for example, Japan's already enacted Revenge Pornography Prevention Law, and the Anti Spy-cam Filming Law which has not been enacted yet but which has been repeatedly tabled in the country's parliament). Third is a kind of intermediate legal approach addressing some of pornography's most brutal harms (especially some production and circulation harms). This is an approach currently adopted in the UK. We consider each of the three approaches in turn, below.

We begin by considering the legal approach of the MacKinnon-Dworkin Ordinance. The Ordinance remains important as the first systematic legal approach to the harms of pornography, although in the end it was not enacted because of US courts judging it unconstitutional. The Ordinance has four characteristics. Firstly, in the 
American tradition of the civil rights movement and civil rights law, the Ordinance explicitly gives pornography a highly political and feminist characterization as a practice of sex discrimination, or a systematic practice of exploitation and subordination based on sex that differentially harms and disadvantages women (MacKinnon \& Dworkin, 1988, p. 138). This theoretical definition is predicated on the Ordinance's intention to exclude sexually explicit but not pornographic materials (such as those in the medical or sex education fields, or literature describing sexual violence) from the definition of pornography.

Secondly, as a natural result of this boundary-setting, the legal definition of pornography in the Ordinance is also an explicitly political and feminist one attuned to this theoretical characterization. The obscenity clauses of criminal laws ordinarily do not include any explicit definition of "obscenity," so courts (and, finally, the Supreme Court) present various definitions of it in their judgements at different times. However, the MacKinnon-Dworkin Ordinance gives a distinct and clear definition of pornography from the outset. As is well known, the Ordinance defines pornography through two steps. It first defines pornography as the "graphic sexually explicit subordination of women through pictures and/or words," and, as a second step, after concretely enumerating a number of descriptions of pornography (for example, (i) women are presented dehumanized as sexual objects, things, or commodities; or (ii) women are presented as sexual objects who enjoy pain or humiliation; or (iii) women are presented as sexual objects who experience sexual pleasure in being raped;... (ix) women are presented in scenarios of degradation, injury, torture, shown as filthy or inferior, bleeding, bruised, or hurt in a context that makes these conditions sexual), the Ordinance descriptively defines pornography as including one or more examples of these (1988, pp. 138-139). These two hurdles that must be jumped to meet the definition of pornography means its designation is strict and narrow, and the definition structurally prevents materials merely depicting nudity qualifying as pornography.

Thirdly, the ordinance is drafted so comprehensively as regulatory legislation that it further addresses general and unspecified harms arising from the social pervasiveness of pornography (harms that the Ordinance calls the trafficking of pornography, and which we call "social harms"), as well as individual harms sustained by specific victims arising in the process of the production and consumption of pornography.

Fourthly, the Ordinance is not a criminal law but a civil law allowing victims or citizens to file civil lawsuits against offenders. Based on the Ordinance, complainants can ask for two things: damages (including punitive ones), and injunctions against the circulation of pornography.

It is obvious that these characteristics are deeply interconnected. Because the social character of pornography is theoretically presented as a "systematic practice of sex discrimination," it is inevitable that the legal definition of pornography also reflects this theoretical understanding as a discriminatory practice inflicting harms of subordination upon women. And because of such a definition of pornography, it is also inevitable that the Ordinance comes to be a law addressing not only individual harms arising from the production and consumption of it, but also social harms generally arising from its circulation. Also, given the legally formal status of pornography as "speech," understandably there is reluctance to enact the provisions of the ordinance in criminal law, which represents the sovereign exercise of power by the state. It is to some extent inevitable, therefore, that the law would apply civilly, rather than criminally, to alternatively place in the hands of victims and citizens sovereign rights of ju- 
dicial redress. Or, we might differently surmise that it is precisely because the ordinance's provisions are enacted civilly that it is able to address pornography's full range of harms.

However, since these above-mentioned four characteristics are based on the specific situation of the United States, they seem to be largely irrelevant to Japan's situation.

Firstly, the United States has a strong tradition of anti-discrimination movements, including the movement for the abolition of slavery in the 19th century, and the civil rights movement of the post-WWII period, so it is not unusual for American laws to incorporate definitions of concepts such as "discrimination" or "subordination." (That said, in the 1980s when the Ordinance was enacted, there was significant opposition to its provisions in American society.) Further, equality rights are heavily emphasized in United States constitutional jurisprudence, and are interpreted by scholars as comprising fundamental human rights. In contrast, Japan in its history has neither a slave liberation movement nor a civil rights movement, and so the country has never been engulfed in an anti-discrimination struggle. Reflecting this history is the failure of constitutional scholars across the board in Japan, even progressive ones, to recognize the importance of the explicit equality guarantee in Japan's postwar constitution.

Accordingly, it would be extremely difficult to imagine how, in Japan, the legal definition of pornography could be expressly captured as the "subordination of women" in law.

Thirdly, because Japan's judicial system does not allow punitive damages, compensation amounts for damages that offenders pay is minimal (at most, a few tens of thousands of dollars), even when a plaintiff wins a civil case. Further, Japan's per capita population of lawyers is one ninth that of the US, and the number of yearly civil cases heard in its courts one eighth. Defendants tried in Japanese courts are found guilty at rates of $99 \%$, and plaintiffs in civil cases win at rates of $80 \%$. But when defendants are corporate entities, this figure drops to less than 50\% (Iida, 2020, p. 136). For example, in 1998, when smoking victims brought civil action against a tobacco company in Japan, different from America where large payouts were awarded in such cases, the case took five years and delivered a negative judgement to the plaintiffs in 2003. Japan's court trials take an extraordinary long time. Once appeals are launched the trials can continue for 10 years, and during this time victim plaintiffs must continue to bear the burden of court proceedings. Most victims buckle under this weight and enter settlement negotiations. In the meantime, defendant pornographers continue producing films while court cases are being heard, continue profiting from them, and continue generating victims. Therefore, a law like the MacKinnon-Dworkin Ordinance addressing all of pornography's harms in one comprehensive civil tool is not realistic in Japan's case.

Further, because the prison system in the United States is very corrupt, top members of criminal syndicates can bribe or intimidate detention officers to live comfortable lives in prison, and even to continue to businesses related to their crimes from within prison through contact with syndicate members on the outside. MacKinnon and Dworkin note that, even when they are sent to jail, pornographers continue running their businesses from the inside, so it is much more effective in their case to impose compensatory or/and punitive damages (1988, p. 54). However, Japan's prison system is not similarly so corrupt.

In any case, coercion in pornography filming and the many other harms of pornography deserve severe criminal punishment, and, we believe, perpetrators should 
not get away with merely paying damages, which, as mentioned, are tiny in Japan. Criminal laws are envisaged as more effective in combatting the harms of pornography when accompanied by strong grass-roots movements and pressure on police and judicial institutions to enforce the laws. Of course, criminal laws must be complemented by civil efforts.

In contrast to the comprehensive civil law of the MacKinnon-Dworkin Ordinance is the approach differently commended here whereby categories of pornography's harms are each addressed through some sort of specific criminal law. One example of this isolated legal approach is Japan's already-enacted Revenge Pornography Prevention Law. This law prohibits and punishes the non-consensual distribution and publication of private (i.e. non-commercial) sexual photographs and footage of individual persons. Therefore, it meets our classification criteria II(2)(a) described as the nonconsensual circulation of sexual pictures taken consensually in terms of tackling a harm of pornography arising from circulation. But materials, once uploaded to the Internet, continue to circulate even when the person who uploaded them is arrested and prosecuted. Or even when the materials are taken down from the Internet, they can always be uploaded again. The current law does not intervene in these dissemination harms. However, in the same way that child pornography is treated in law, continuing to make these sorts of materials available or accessible on the Internet, downloading them, or keeping them in personal digital storage should be treated as a criminal matter. Criminalization of these further acts has already been achieved in South Korea.

The above-mentioned Revenge Pornography Prevention Law is applied to the publication and distribution of sexual photos and movies filmed by spy-cameras. However, there is no nation-wide law against spy cam filming itself in Japan. There are local council ordinances in Japan banning spy-cam filming, but definitions of spy-cam filming vary by jurisdiction, and so it is sometimes the case that spy-cam filming in public places is the only form of the crime that is prohibited, and definitions of 'public place' also vary according to jurisdiction. So now a movement to enact a nation-wide anti-spy-cam law has come about. If an anti-spy-cam law is enacted, the law could be applied to crack down on other non-consensual filming of sex acts or naked bodies in non-commercial context, too, for example, the act of filming when conducting sexual assault or sexual harassment (see 2(a) of our Production Harms classification). Such a new law would effectively mean Japan's Revenge Pornography Prevention Law will apply to the publication and distribution of sexual photos or movies produced by spycam filming.

Similarly, mash-up or deepfake pornography comprising super-imposed, collage pictures and film (included in our circulation harms of pornography, subcategory 3 ) is likely to be a suitable candidate for individually targeted legislation. These collage products themselves are not realistically addressed in criminal law, because they are deeply intertwined with values of freedom of speech, given their common use in political satire and lampooning cartoons. Accordingly, subjecting collage materials to the criminal law is risky because of its possible misuse in political suppression. In instances where these materials do inflict harm on individuals, therefore, civil suits for defamation are more appropriate. However, in the case of sexualized collage and mash-up materials, freedom of speech imperatives do not apply, because materials designed to sexually degrade individuals cannot be imagined as having any high political purpose.

These kinds of specifically targeted laws are criminal laws in principle. This kind of criminal law addressing specific harms of pornography has some advantages. First, since the law addresses one particular harm, its provisions can apply specialized legal 
remedies fitting the specific harm. Also, the law's target and purpose are limited and precise, so it is not difficult to enforce. And, because such law addresses specific harm, rather than pornography itself, it is not so likely that an oppositional movement on the grounds of freedom of expression will come about, so it is relatively easy to enact. Additionally, since it is criminal law, it is the police's role to investigate and arrest offenders. But, as MacKinnon says:

The best thing about criminal law is that the state does it, so women do not have to. The worst thing about criminal law is that the state does not do it, so women still have to (MacKinnon, 1993, p. 29).

Both rape and indecent assault are criminal matters, but offenders are rarely arrested. Even when they are arrested, more than half are not prosecuted. And, even when they are prosecuted, convictions are rare. The same can be said of specific laws addressing specific harms of pornography. Therefore, even if this kind of law is established, it is still civil society's task to have administrative institutions do public awareness-raising on the law, have the police enforce it, and monitor and encourage the judicial system to bring offenders to justice. If this is borne in mind, specific laws addressing pornography's specific harms can be effective.

However, these good points are in parallel to its bad points. Pornography's harms do not exist in isolation but in connection with each other, based on the underlying existence of pornography. Individual harms of pornography derive from the inherently violating character of it, so it is not enough to address pornography's visible and specific harms while ignoring connections between them. This leaves the cause of the harms untouched and deals only with its most noticeable results. Accordingly, this piecemeal and specific legislative approach can remedy only a small portion of pornography's vast harms. Thus, it has a deficiency in that most of these harms (significantly, harms arising from commercial pornography) remain untouched. Therefore, this approach should be supplemented by a more comprehensive policy.

A legal proposal by Human Rights Now (HRN) (a Japanese human rights NGO, represented by lawyer Kazuko Itou) published in March 2016 can be seen as representing an approach that sits in an intermediate position between the comprehensive legal approach of the MacKinnon-Dworkin ordinance and laws addressing specific harms of pornography. Through interviews with actual victims of pornography's harms, and with members of NGOs (such as PAPS and Lighthouse) that support them, HRN published a Research Report into Human Rights Violations against Women/Girls through Pornography and the Pornography Industry, which proposes the concrete regulation of some of pornography's harms, focusing on coercion in pornography filming (2016).

The Research Report, first and foremost, insists that coercing someone to appear in pornography is "violence against women, and hence a human rights violation," and that "the state has an obligation to eradicate and prevent the harms, and to protect victims and give relief to them," and demand criminal punishment. Also, the Report states that "solicitation for the filming of pornography through coercion, fraud, and confusion" should be banned. Furthermore, bearing in mind various concrete cases based on interviews with victims, the Report recommends prohibiting "solicitation for appearance in pornography where the solicitation targets an unspecified number of people in public places," as well as "solicitation of a person who explicitly declines to enter into a contract offered as part of the solicitation." And the Report demands that, when establishing contracts, the pornography industry should beforehand explain the fact that this work "falls into the category of harmful and dangerous work 
under the Worker Dispatch Law and the Employment Security Act," and "agreement to contract for appearance in pornography can be always withdrawn and discharged." The last clause is important because most young women forced to sign contracts to appear in pornography are induced to believe that they must observe the contract to the end once they have signed a contract in any situation.

These are suggestions addressing coercion harms of pornography (in terms of our classification, "1-a" and "1-b" of the specified production harms). In addition to that, the Report includes a suggestion that reaches even further to address aspects of the content of pornography. It insists that, in filming pornography, "the acts should be basically prohibited that can have a negative effect on the mental and physical safety and health" of cast members. In terms of our classification, this falls into " 1 -c" of production harms. In addition to acts "which can have a negative effect on mental and physical safety and health," we believe that acts that "hurt performers' dignity" also should be prohibited.

There will inevitably be disagreement as to what is concretely envisaged by the prohibition of acts "which can have a negative effect on mental and physical safety and health." However, at a minimum, physical violence towards performers, deep-throating, choking, the unsanitary ingestion and handling of feces and other bodily excretions, unprotected sex, especially internal ejaculation without condoms, multiplepartner simultaneous penetration, multiple-partner continuous penetration, anal sex, bestiality, penetration with foreign objects, defecation and similar private acts in front of others or the camera, forcible ingestion of alcohol, water or other food and drink, excessive friction and rubbing of genital areas, filming in dangerous or unsanitary places, filming in public places, and filming in places accessible to the public, among other practices should be prohibited. We additionally believe that penile penetration itself, when it is undertaken for the purpose of commercial pornographic filming, should be legally restricted for its direct impact on the safety, health, and dignity of performers.

Also, the Report demands total or partial suspension of malicious businesses and recommends "injunction on the sale" of works produced by coercion, fraud, or involving insufficient preliminary explanation, and insists upon the criminal punishment (imprisonment or criminal fine) of offenders. In respect of our classification scheme, these recommendations comprise legal measures against subcategory (1) of "circulation harms." The Report incorporates suggestions for redress beyond mere legal penalty because it asks the government to nominate a ministry to assume regulatory responsibility for the pornography industry, and recommends government take responsibility for providing consultation and counseling services for victims, and, as mentioned above, it insists that materials that "have a negative effect on mental and physical safety and health" should be prohibited as a rule, and that "injunction on the sale" of works should be imposed when they have been produced through coercion or fraud. If the HRN-recommended law is enacted, therefore, it will mean avenues of legal redress will become available for pornography's production harms as well as some of its circulation harms.

While these HRN legal recommendations primarily focus on production harms starting with coercion in pornography filming, HRN does not propose any specific law to address production harms more fundamentally. The report's recommendations do not confront the underlying abusiveness intrinsic to pornography, which produces numerous human rights violations. The recommendations address in isolation the 
kinds of harms that can be identified with individual victims. Hence, other harms, particularly social harms of pornography whose victims are unspecified, are left unaddressed.

\section{Our Strategic Alternative}

Specific laws addressing specific harms and the intermediate approach of HRN, due to their focus on harms whose victims are specified individuals, can be constructed as criminal laws. Still, they cannot address the rest of pornography's harms, especially its consumption and social harms. Nor do these laws have any intent to do so. Therefore, we need to envisage a new comprehensive legal approach that can bestow each approach's advantages and compensate for deficiencies.

This new comprehensive law would not displace specific laws or HRN's legal proposal but is envisaged as complementing them. It will be difficult to enact comprehensive legislation because there will be strong resistance from dominant currents of Japanese society, and, of course, inevitably, we would come up against freedom of expression arguments, and this would cause long delays in its enactment, and, in fact, would likely prevent its enactment altogether. We must learn the lessons of the failure of the McKinnon-Dworkin Ordinance. While we campaign to establish various specific laws (such as the Spy-cam Filming Prevention Law) and the legal proposal suggested by HRN centering on coerced filming, at the same time we must envisage and construct complementary legislation in a comprehensive way that addresses other forms of pornography's harms (particularly its consumption harms and social harms).

Furthermore, this law would not displace existing criminal regulations against obscene materials. While we agree with MacKinnon's criticism of the obscenity approach, we believe that criminal obscenity regulations are far from meaningless and instead can be partially applied to the environmental harm of pornography that comprises social harms. We can still apply regulations against obscene materials by converting their application criterion from moralism to human rights (and precisely the person's dignity and equality). Legal obscenity breaches are recognized in Japan if materials show genitals unblurred. Genitals are obviously the most private parts of the human body and are central to individual sexual dignity. From a human rights perspective, it is right that their explicit depiction for the purpose of sexual stimulation, and the public release and distribution of such materials, is criminally regulated, irrespective of the consent of individuals to such activity.

We shall call our proposal for supplementary comprehensive legislation the Pornography's Harms Prevention Law. But we need not conceive of this law as a standalone piece of legislation. The law can be enacted as a cluster of relevant regulations or as part of more comprehensive legislation such as provisions within laws against sexual violence. Our proposed legal approach would establish both criminal and civil avenues for redress. Harms that are not covered or that are difficult to cover in specific laws, or the legal suggestion of HRN; that is, harms relating to pornography's consumption, social impact, and existence, should be given civil avenues of redress, while criminally actionable harms should be afforded regulatory and legislative options. Instead of the explicitly feminist subordination of women definition, it is more realistic to make the legal definition of pornography one which invokes the definition of child pornography in Japan's existing Child Pornography Prohibition Law, in which poses and acts "relating to sex or similar to sex" or with "clothing removed fully or partly," and "exciting or stimulating sexual desire," or "inordinately highlighting or exposing sexual parts" comprise breaches. 
To be sure, it would be ideal to legally define pornography as a systematic practice of sex discrimination and subordination of women (in this case, pornography is factually defined as something that comprises harm to women) and to comprehensively regulate the harms arising from it. But, as already mentioned, this approach would be challenging in Japan. Even in the United States, this effort, after all, failed. So, we believe that it would be better to separate the definition of pornography from its harms and maintain the appearance of dealing with pornography's harms instead of pornography itself. This is not only because it would become easier to pass in Japan's legislature, but also because, even if the material is not something subordinating of women (for example, footage of sex between a man and a woman who love each other), the non-consensual distribution of it through the Internet nonetheless produces serious harms.

Our proposed law would address consumption and social harms arising from pornography's widespread circulation and would incorporate different legal responses to these harms according to their type. Regarding consumption harms, since forcing pornography on someone at home or at work (as per No. (1) in our classification scheme above of consumption harms) is a kind of domestic violence or sexual harassment at work, naturally, we should address these harms through criminal punishment. In relation to sexual violence incited by certain kinds of pornography (especially violent materials), which comprises consumption harm No. 2 in our classification scheme above, just as in the MacKinnon-Dworkin Ordinance, victims would be able to sue producers of the materials. Creating this avenue of redress would not be an unrealistic measure: similar claims for damages are brought against tobacco companies for producing products that have harmed an individual's health.

Next, in respect of social harms, for environmental harms of pornography (item No. (1) of our classification scheme above of social harms) we should use a means of social enlightenment activity, administrative guidance, and recommendation by government. As for declines in women's status brought about by pornography's pervasiveness (which is item No. (2) in our classification scheme above on social harms), we need different strategies according to the content of the pornography under consideration.

On the one hand, in the case of live-filmed pornography, given the HRN understanding that it has "negative effects on the mental and physical safety and health" of cast members, and potentially injures "her or his dignity," the production, as well as the distribution of such materials, should be treated as a criminal matter. Also, even when the materials comprise non-live-filmed pornography (such as paintings, animation, and CG), it is possibly enough to treat the distribution and publication of such pornographic content as criminal, including materials that imitate or promote crimes such as rape, molestation, detention or public indecency, or materials in relation to which, if the acts they depict were done to a real person, would "have certain negative effects" on a person, or would "hurt her or his dignity." We can classify these types of non-live-filmed pornography as "violent pornography." Given that, in the UK, pornography in which cruel and brutal acts (for example, bestiality and necrophilism) are already prohibited, this is not an unrealistic proposal.

On the other hand, even when not "violent" in the sense mentioned above, we should make some kinds of pornography civilly actionable as the MacKinnonDworkin Ordinance does, including materials that reduce women to a sexually subordinate existence, or present women as mere sexual objects, or describe women in a way that reduces them to their body parts, or shows an adult woman as if she is a child, etc. We can refer to these kinds of pornography as subordinate pornography. The 
MacKinnon-Dworkin Ordinance defined the distribution of both these mentioned above - "violent pornography" and "subordinate pornography" - together as "trafficking" to make them civilly actionable. Still, we believe they should be separately addressed: the former criminally, and the latter civilly. Our proposed approach would address "harms of circulation" (those not yet addressed) and "harms of pornography's existence." In other words, it would ban the private possession of materials that are subject to a ban, as well as the hosting or Internet display of such materials, which have been judged to engender harms in their production or their circulation, or which were used as a means of intimidation in private relations. Alternatively, it would be possible to improve upon the specific laws and legal recommendations of HRN towards prohibiting these materials.

Moreover, in our proposal, legal provisions would be enacted to confiscate all revenues earned through the distribution or sale of pornography produced through the coercion or intimidation of victims or through spy-cam filming. These proceeds of crime would be re-distributed to victims. In South Korea, a 2020 criminal code amendment saw the introduction of legal powers to confiscate revenues earned through the production of deepfake pornography. These powers should be exercised for other victims of pornography production. If such provisions were introduced in Japan, the country's pornography industry would sustain substantial economic damage, and some degree of financial compensation could be given to victims.

Thus, we have discussed five points arising in relation to our new legislative vision. To what extent the Pornography's Harms Prevention Law would cover pornography's harms would depend on levels of development of human rights awareness and the women's movement. If these levels are low, the range of "violent pornography" and "subordinate pornography" that could be regulated under the new law would be interpreted narrowly. But, on the other hand, if human rights awareness in society was developed, and if the strength of the women's movement was evident, the law would be able to cover almost the full range of pornography defined in the MacKinnon-Dworkin ordinance. We advocate a strategic, step-by-step approach that starts by addressing pornography's particularly severe harms and then widens its range of regulation against the broader spectrum of pornography's harms, and finally encroaches upon pornography itself (pornography's harms include, after all, pornography itself). By adopting this legal strategy, on the one hand we can address the most serious and vicious forms of pornography's harms right now, and, on the other hand, with the future development of social consciousness and growth in the women's movement, we will finally be able to address pornography as a systematic practice of sex discrimination. This is an approach realistic in practice and justifiable in principle.

\section{ACKNOWLEDGMENTS}

The authors thank members of the Anti-Pornography and Prostitution Research Group (APP) and People Against Pornography and Sexual Violence (PAPS). Dignity thanks the following people for the time and expertise to review this article: Catharine A. MacKinnon, Elizabeth A. Long Professor of Law at University of Michigan Law School; and Hiroshi Nakasatomi, Osaka Electro-Communications University. 


\section{AUTHOR BIOGRAPHIES}

Seiya Morita (D https://orcid.org/0000-0002-8343-1265 lectures in Marxist political economy at Kokugakuin University in Tokyo and is a member of the Anti-Pornography and Prostitution Research Group. He is the translator of Catharine MacKinnon, David Harvey, and Sheila Jeffreys's work into Japanese. His English-language academic work is published in Oriens Extremus, The Asia-Pacific Journal Japan Focus, and Dignity: A Journal on Sexual Exploitation and Violence. Morita reads in English, Russian, Japanese, and German, and is an internationally recognized Trotsky studies expert.

Caroline Norma (D) https://orcid.org/0000-0002-6836-2054 lectures in translation and interpreting at RMIT University in Melbourne and is a member of the Coalition Against Trafficking in Women Australia. Her English-language academic work is published in Asian Studies Review, Women's Studies International Forum, and Dignity: A Journal on Sexual Exploitation and Violence. Norma reads in Japanese and English and has expertise in the history of the comfort women, military prostitution, and the theorizing of Carole Pateman.

\section{RECOMMENDED CITATION}

Morita, Seiya \& Norma, Caroline. (2021). Pornography, its harms, and a new legal strategy: Research and experience in Japan. Dignity: A Journal of Analysis of Exploitation and Violence. Vol. 6, Issue 2, Article 3. https://doi.org/10.23860/dignity.2021.06.02.03

Available at http://digitalcommons.uri.edu/dignity/vol6/iss2/3

\section{REFERENCES}

"A convicted sex offender reflects on pedophilia and sex crime prevention: child pornography was a trigger, still today, I get a thrill just seeing the word 'child."' (18 December 2019). Abema Times.

"A man using many women to organize a gang of spy cam photographers was arrested for the first time in Japan." (29 November 2002). Tokyo Shimbun [in Japanese].

Amaki, Riu (2007). "Crimes in adult videos." Days Japan [in Japanese].

Amaki, Riu. (2008). "The live recording of sex crime videos finally judged." Days Japan [in Japanese].

Bin Liang and Hong Lu. (2012). Fighting the obscene, pornographic, and unhealthy-an analysis of the nature, extent, and regulation of China's online pornography within a global context. Crime, Law, and Social Change, 58.2: 111-130. https://doi.org/10.1007/s10611-012-9380-3

Days Japan investigative committee, Report, December 2019 [in Japanese].

Dworkin, Andrea. (1993) "Pornography's part in sexual violence." Letters from a war zone, Lawrence Hill Books.

"Edogawa ward high school girl murder: 'choking' pornography DVDs found in arrested man's room." (17 November 2015). FNN [in Japanese].

"Female escort prostitute secretly filmed at house of 41-year-old corporate employee with mobile phone placed on windowsill," Kobe Shimbun, 16 December 2019 [in Japanese].

"Former pornography actress Asuka Hoshino opens up about coerced filming: 'I still live with the trauma."' (26 November 2016). Bengoshi dot.com News [in Japanese].

"Former TV personality Matsumoto Ayase speaks about being used in pornography filming: 'there's a tendency to blame victims who are tricked." (27 May 2016). Bengoshi dot.com News [in Japanese].

"Four high school students unclothe and kick their classmate, upload its footage to the Internet." (13 November 2014). Yomiuri Shimbun [in Japanese]. 
Fujita, Kumiko. (2003). Why does chikan continue?: in-depth exploration of the social mechanism of acceptance of chikan. Otemon Gakuin University Gender Free Style Institute [in Japanese].

Honoka, [no first name]. 2010. The cage. Shufunotomo-sha. [in Japanese].

Human Rights Now. (2016). Research report into human rights violations against women/girls through pornography and the pornography industry [in Japanese].

"I developed an interest in it through watching rape pornography," said the man who sexually assaulted women. (26 September 2017). Nittere News [in Japanese].

"I was very scared about confronting adult men," victimized woman said after the trial on pornography appearance breach fees. (1 October 2015). Bengoshi dot.com News [in Japanese].

Ibroscheva, Elza. (2016). Bulgaria: regulating pornography in the new digital realities, Internet Policy Review: Journal on Internet Regulation, Alexander von Humboldt Institute for Internet and Society (HIIG), Berlin, vol. 5(4), pp. 1-12.

Iida, Ko. (2020). Natural persons and corporate entities in civil trials. Shakaikagaku Kenkyuu Kiyo, Vol. 71, issue 2 [in Japanese].

Ito, Shiori. (2017). Black box, Tokyo, Bungei Shunju,

"Japan Self-Defense Forces member arrested for procuring women through pay-day loans, 'who would ask for underwear shots as security for a loan!",' TBS News, 28 November 2019 [in Japanese].

Konan University Graduate Gender Research Group. (2000). Pornography in everyday life: 59 women describe their experiences and thoughts [in Japanese].

MacKinnon, Catharine \& Andrea Dworkin. (1988). Pornography and civil rights: A new day for women's equality. Organizing against pornography.

MacKinnon, Catharine. (2005). Civil rights against pornography. Women's lives, men's laws.

MacKinnon, Catharine. (1991). From practice to theory, or what is a white woman anyway? Yale Journal Law \& Feminism, Vol. 4.

MacKinnon, Catharine. (1993). Prostitution and civil rights. Michigan Journal of Gender \& Law, Vol. 1, 1993.

MacKinnon, Catharine A. and Andrea Dworkin eds. (1998). In harm's way: the pornography civil rights hearings, Cambridge, MA: Harvard University Press.

"Man who threatened public release of nude footage re-arrested: footage of more than 100 women discovered." (10 December 2019). FNN [in Japanese].

"Miyazaki rape videos: the female victim writes about it, 'I felt my life was over."' (21 January 2015). Mainichi Shimbun [in Japanese].

Morgan, Robin. (1977). Theory and practice: pornography and rape. Going too far: the personal chronicle of a feminist, Random House.

Norma, Caroline and Morita, Seiya. (2020). Feminist action against pornography in Japan: unexpected success in an unlikely place. Dignity: A Journal on Sexual Exploitation and Violence: Vol. 4: Iss. 4, Article 4. https://doi.org/10.23860/dignity.2019.04.04.04

No Status Quo. (No date)._Nikki Craft, The silencing of women's speech, http://www.nostatusquo.com/ACLU/Porn/silencing.html.

"Now impossible to take down?": Circulation of pornography that victims don't remember shooting, and which no longer blurs body parts: problems befalling an ex-pornstar.' (13 August 2019). Bengoshi dot.com News [in Japanese].

Pornhub. (2019). 'The 2019 Year in Review,' https://www.pornhub.com/insights/2019-yearin-review.

"Re-arrest under revenge pornography law of man caught spy-cam filming patrons of a public toilet." (26 October 2018). Higashi Supo Web. 
"Recommended sentence." (14 June 2005). ESPIO! [in Japanese].

"Recruiting for modelling and entertainment industry work, 'filming sex acts that are not contracted or agreed to."' (8 February 2017). Bengoshi dot.com News [in Japanese].

"Secretly filmed footage found of hundreds of victims filmed in a public toilet: 'the targets were secondary school students."' (13 June 2018). Kyoto Shimbun [in Japanese].

Tankard Reist, Melinda; Bray, Abigail. (2011). Big Porn Inc: exposing the harms of the global pornography industry. North Melbourne, Vic: Spinifex Press.

"The day the erotic books were vanishing." (2019). Etcetera, Vol. 1 [in Japanese].

“The fake 'naked graphics' of actresses cannot be legally excused on the basis there's merely a 'penalty of fame."' (6 July 2016). Bengoshi dot.com.News [in Japanese].

“"There's a clip online that looks like you..." man arrested for publicly posting spy-cam footage found by victim after be alerted by an acquaintance,' Kobe Shimbun, 11 July 2019 [in Japanese].

"This injures someone: the meaning of keeping adult magazines out of convenience stores." (25 January 2019). Buzz Feed News [in Japanese].

"YouTuber Kuromin Aroma posts video about being tricked into pornography filming: I hope it acts as a deterrent to others." (3 September 2016). Bengoshi dot.com News [in Japanese].

"Victims of spy-cam filming fall through the cracks of policing: 'We have no choice but to live the rest of our lives in fear."' (2 December 2018). Bengoshi dot.com News [in Japanese].

"Victims' lawyer calls for enactment of new criminal law against spy-cam filming." (12 July 2018). Mainichi Shimbun [in Japanese].

Waltman, Max. (2014). The politics of legal challenges to pornography: Canada, Sweden, and the United States. PhD Dissertation. Stockholm University, 2014.

"'Watching child-themed pornography' led to crimes against five primary school-aged girls." 20 October 2016. Sankei Shimbun.

Yamamoto, Yukino; Norma, Caroline; and Weerasinghe, Ruwan Dep. (2018). Consumer involvement in Japanese pornography production. Dignity: A Journal on Sexual Exploitation and Violence: Vol. 3: Iss. 2, Article 9. https://doi.org/10.23860/dignity.2018.03.02.09

Yamashita, Shinji. (20 October 2019). “I was so scared I couldn't run away”: Internet figurines promoter recalls her experience of being tricked nine years earlier." Bengoshi dot.com News [in Japanese]. 